Article

\title{
Nematicidal Evaluation and Active Compounds Isolation of Aspergillus japonicus ZW1 against Root-Knot Nematodes Meloidogyne incognita
}

\author{
Qiong He ${ }^{1}$, Dongya Wang ${ }^{1}$, Bingxue $\mathrm{Li}^{1}{ }^{1}$, Ambreen Maqsood ${ }^{1,2} \mathbb{D}$ and Haiyan $\mathrm{Wu}^{1, *}$ \\ 1 Guangxi Key Laboratory of Agric-Environment and Agric-Products Safety, Agricultural College of Guangxi \\ University, Nanning 530004, China; heqiong3344@163.com (Q.H.); wdy15677131171@163.com (D.W.); \\ 18437958381@163.com (B.L.); ambreenagrarian@gmail.com (A.M.) \\ 2 Department of Plant Pathology, Faculty of Agriculture and Environmental Sciences, The Islamia University \\ of Bahawalpur, Bahawalpur 63100, Pakistan \\ * Correspondence: whyzxb@gmail.com
}

Received: 23 July 2020; Accepted: 16 August 2020; Published: 19 August 2020

check for updates

\begin{abstract}
The root-knot nematode is one of the most damaging plant-parasitic nematodes worldwide, and the ecofriendly alternative approach of biological control has been used to suppress nematode populations. Here the nematicidal activity of Aspergillus japonicus ZW1 fermentation filtrate against Meloidogyne incognita was evaluated in vitro and in greenhouse, and the effects of $A$. japonicus ZW1 fermentation filtrate on seed germination and the active compound of $A$. japonicus ZW1 fermentation filtrate were determined. The 2-week fermentation filtrate (2-WF) of A. japonicus ZW1 exhibited markedly inhibitory effects on egg hatching, and 5\% 2-WF showed potential nematicidal activities on second-stage juveniles (J2s); the mortality of J2s was $100 \%$ after $24 \mathrm{~h}$ exposure. The internal contents of nematodes were degraded and remarkable protruded wrinkles were present on the body surface of J2s. The nematicidal activity of the fermentation was stable after boiling and was not affected by storage time. A germination assay revealed that 2-WF did not have a negative effect on the viability and germination of corn, wheat, rice, cowpeas, cucumbers, soybeans, or tomato seeds. The pot-grown study confirmed that a $20 \%$ fermentation broth solution significantly reduced root galls and egg numbers on tomatoes, and decreased galls and eggs by $47.3 \%$ and $51.8 \%$ respectively, over Czapek medium and water controls. The active compound from the $A$. japonicus ZW1 fermentation filtrate was isolated and identified as 1,5-Dimethyl Citrate hydrochloride ester on the basis of nuclear magnetic resonance (NMR) and LC-MS (liquid chromatograph-mass spectrometer) techniques. Thus, fermentation of $A$. japonicus ZW1 could be considered a potential new biological nematicide for the control of M. incognita.
\end{abstract}

Keywords: biocontrol Aspergillus japonicus; root-knot nematode; fermentation filtrate; biological control; seed germination

\section{Introduction}

Root-knot nematodes (Meloidogyne spp.) are economically important worldwide pathogens causing considerable damage to many crops, including cucumbers, tomatoes, rice [1-4], and even cotton [5,6]. Meloidogyne incognita is an important species of root-knot nematodes worldwide due to its direct impact on crop yields [7-9]. Specifically, it is capable of causing an estimated yield loss of 5-43\% within vegetable crops cultivated in tropical and subtropical areas [10] and estimated $\$ 100$ billion loss per year worldwide [11].

Due to their short life cycle and high reproduction rates, these root-knot nematodes have been particularly challenging to control. Previously, chemical nematicides are efficiently used to suppress 
nematode populations, such as fenamiphos, sebufos, dazomet, and carbofuran [12]; however, these have been found to be harmful to both the eco-environment and human health due to their toxic effects. Thus, as a result of these negative impacts and the significant economic losses which can result from nematodes, new and alternative biological control options are urgently needed [13]. Therefore, the use of biological agents to suppress the population of plant-parasitic nematodes could provide an alternative strategy to sustainably manage plant-parasitic nematodes. Using biofumigation instead of harmful fumigants (like synthetic nematicide methyl bromide) to control nematodes is an increasingly feasible method of parasitic nematode management [14]. Plants such as Melia azedarach have been found to be potential sources of biofumigation plant material to control Meloidogyne spp. on tomato [15]. Moreover, microbial agents for the control of plant-parasitic nematodes is also a potential method; such as bacteria [16,17], fungi [18,19] and actinomycetes [20], which are nematophagous or antagonistic for root-knot nematodes. Specifically, Arthrobotrys irregularis, Pochonia chlamydosporium, Paecilomyces lilacinus, Myrothecium verrucaria, bacteria Pasteuria usgae, Bacillus firmus, Burkholderia cepacia, Pseudomonas fluorescens, and Streptomyces avermitilis [21,22] have been commercially used in many countries for the control of plant-parasitic nematodes. Some potential microbial sources were constantly obtained, volatiles from beneficial bacteria (Bacillus sp., Paenibacillus sp. and Xanthomonas sp.) can control M. graminicola second-stage juveniles (J2s) on rice and significantly reduced infection of susceptible rice [23]. Co-inoculation of Streptomyces spp. strains KPS-E004 and KPS-A032 showed success in suppressing root-knot nematode [24].

In our previous study, A. japonicus ZW1 culture filtrate was shown to have marked nematicidal activity against $M$. incognita. As a result, the main objective of this work was to evaluate the potential biological control of A. japonicus ZW1 against root-knot nematodes including: (1) the nematicidal activity of A. japonicus ZW1 fermentation filtrate on eggs and J2s within pot and in vitro experiments; (2) electron microscopic evaluation of J2 bodies after treatment with 2-week fermentation filtrate (2-WF);

(3) effect of boiling and storage time on nematicidal activity stability of the fermentation filtrate; and

(4) evaluation for the effect of $A$. japonicus ZW1 fermentation filtrate on the germination of various crop seeds.

\section{Materials and Methods}

\subsection{Nematode Preparation}

Tomato seeds (cv. Xin Bite 2 F1) were sourced from Yashu Garden Seeds Co., Ltd., (Guangzhou, China) and were used to generate seedlings for culturing the M. incognita. For the nematodes culture, one-month-old tomato seedlings were transplanted into pots $(7 \times 7 \times 8 \mathrm{~cm})$ with second stage juveniles of root-knot nematode-infected peat moss (Gui Yu Xin Nong Technology Co., Ltd., Nanning, China) and maintained at $25^{\circ} \mathrm{C}$ with a $14 \mathrm{~h}$ light (22000 Lux) and $10 \mathrm{~h}$ dark photoperiod treatment within a GXZ-280C incubator (Jiangnan Instrument Factory, Ningbo, China). Tomato roots were collected 35 days after inoculation and were gently rinsed with tap water. Eggs were then extracted with $1 \%$ $\mathrm{NaOCl}$ [25] and hatched at $25^{\circ} \mathrm{C}$ using the modified Baermann funnel method [26]. Eggs were put in $30 \mathrm{im}$ pore sieves, nested in petri dishes $(6 \mathrm{~cm}$-diameter) containing $3 \mathrm{~mL}$ distilled water, and the fresh $\mathrm{J} 2 \mathrm{~s}$ in water were then collected on the day of experiment and used for subsequent experimentation.

\subsection{Fermentation Filtrate Preparation}

A. japonicus ZW1 from soil was deposited in the China Center for Type Culture Collection (accession number CCTCC No. M 2014641) and GenBank (accession number KR708636.1). One $\mathrm{cm}^{2}$ potato dextrose agar (PDA) with a fresh culture of A. japonicus ZW1 (cultured 3-5 days at $25{ }^{\circ} \mathrm{C}$ ) was inoculated in triangular flasks with $100 \mathrm{~mL}$ Czapek medium $\left(\mathrm{NaNO}_{3} 0.2 \mathrm{~g}, \mathrm{KCl} 0.05 \mathrm{~g}, \mathrm{FeSO}_{4}\right.$ $0.001 \mathrm{~g}, \mathrm{~K}_{2} \mathrm{HPO}_{4} 0.1 \mathrm{~g}, \mathrm{MgSO}_{4} 0.05 \mathrm{~g}$, Sucrose $3.0 \mathrm{~g}, \mathrm{H}_{2} \mathrm{O} 100 \mathrm{~mL}$ ) and incubated in a MQD-S2R shaker (Minquan Instrument Co., Ltd., Shanghai, China) at $150 \mathrm{rpm}$ and $25^{\circ} \mathrm{C}$ [27] for 3 consecutive weeks, with 10 triangular flasks replicates per week. Czapek medium without inoculation was used as a 
negative control. At the end of the 3-week period, fermentation broth from a total of 30 conical flasks was then filtered using $0.45 \mu \mathrm{m}$ Millipore filters (Whatman, Clifton, NJ, USA) and 1-week fermentation filtrate (1-WF), 2-WF, and 3-week fermentation filtrate (3-WF) were prepared. The concentration of $2.5 \%$ (i.e., fermentation filtrate volume: sterilized water volume $=1: 39), 5 \%(1: 19), 10 \%(1: 9), 20 \%(1: 4)$ and $50 \%$ (1:1) of 1-week fermentation filtrate(1-WF), 2-week fermentation filtrate (2-WF), and 3-week fermentation filtrate (3-WF) were used and 20\% Czapek medium and sterilized water were used as control.

\subsection{Effect of Fermentation Filtrate on Meloidogyne Incognita Egg Hatching}

Fresh eggs were treated with 2.5\%, 5\%, 10\%, 20\%, and 50\% 1-WF, 2-WF, and 3-WF; and also 20\% Czapek medium and sterilized water as controls. The specific experimental conditions were as follows: approximately 100 eggs and $200 \mu \mathrm{L}$ of different concentrations of fermentation filtrate were dispensed into each well of 96-well plate, with 4 replicates for each treatment. Additionally, all experiments were performed in triplicate. The initial number of eggs was counted, and the hatched J2s were recorded using an inverted microscope (Ti-S, Nikon Instruments Inc., Tokyo, Japan) at 0, 3, 6, 9, 12, 15 d after exposure in the dark at $25^{\circ} \mathrm{C}$. The cumulative hatching rate was calculated using the following formula: cumulative hatching rate $=($ the number of hatched $\mathrm{J} 2 \mathrm{~s}) /($ the initial number of eggs $) \times 100 \%$.

\subsection{Nematicidal Activity of Fermentation Filtrate on Meloidogyne Incognita J2s}

Approximately 60 fresh J2s were contained in each well of a 96-well plate and treated with $200 \mu \mathrm{L}$ of $2.5 \%, 5 \%, 10 \%, 20 \%$, and 50\% 1-WF, 2-WF, and 3-WF, 20\% Czapek medium and sterilized water. The number of dead nematodes were counted using a Ti-S Nikon microscope (Nikon Instruments Inc., Tokyo, Japan) at 6, 12, 24, $48 \mathrm{~h}$ after treatment with the solutions and pictures were taken at each time point except for $48 \mathrm{~h}$. It wax determined whether he bodies of dead J2s were straight and lacking movement even after mechanical prodding [28,29]. The test was conducted at $25{ }^{\circ} \mathrm{C}$ in the dark and the experiment was replicated 4 times. J2 mortality was calculated for each well as follows: mortality $=($ the number of dead $\mathrm{J} 2 \mathrm{~s} /$ total $\mathrm{J} 2 \mathrm{~s}) \times 100 \%$. This experiment was performed a total of three times.

\subsection{Scanning Electron Microscopy Observations}

J2s were treated with $10 \%$ 2-WF for $10 \mathrm{~h}$ and subsequently analyzed with scanning electron microscopy (SEM) using the approach as described below [30,31]. In preparation for the microscopic evaluations, J2 specimens were fixed in $2.5 \%$ glutaraldehyde with $0.1 \mathrm{M}$ phosphate buffer ( $\mathrm{pH} 7.2)$ at $4{ }^{\circ} \mathrm{C}$ overnight and subsequently washed 3 times in $0.1 \mathrm{M}$ phosphate buffer. Afterwards, they were then fixed in $1 \%$ osmium tetroxide for $2 \mathrm{~h}$, washed 3 times in $0.1 \mathrm{M}$ phosphate buffer again, dehydrated in a graded series of ethanol, critical point dried with Quorum K850 critical dryers (Emitech, East Sussex, England, UK) and finally sputter coated with MSP-2S gold-palladium (IXRF, Austin, TX, USA). Prepared J2 specimens were observed using a SU8100 scanning electron microscope (Hitachi, Tokyo, Japan) operating at $3.0 \mathrm{kV}$ accelerating voltage.

\subsection{Transmission Electron Microscopy Observations}

The technical approach was very similar to the aforementioned method described for 'scanning electron microscopy observations'; however, after J2s were dehydrated with ethanol, they were subsequently embedded in Araldite (Sigma-Aldrich, Sigma-Aldrich LLC., Darmstadt, Germany). To enable evaluation of the specimens, ultrathin sections $(70 \mathrm{~nm})$ were obtained using an EM UC7 ultramicrotome (Leica, Wetzlar, Germany) with a Diatome Ultra $45^{\circ}$ diamond knife (Diatome Ltd., Helmstrasse Nidau, Switzerland). Sectioned samples were then stained with uranyl acetate and lead citrate using carbon film copper 500 mesh [30,32]. Sections of the J2 bodies were then observed using an HT7700 transmission electron microscope (Hitachi, Tokyo, Japan) operating at an $80.0 \mathrm{kV}$ accelerating voltage. 


\subsection{Greenhouse Experiment}

Thirty day old (3-4 leaf stage) healthy tomato seedlings (cv. Xin Bite 2 F1) were transplanted in a pot $\left(785 \mathrm{~cm}^{3}\right)$ containing $250 \mathrm{~g}$ autoclaved and dried peat moss. A total of 2000 fresh J2s were inoculated in each pot at 3 days after transplanting. Subsequently, $130 \mathrm{~mL}$ of $20 \%$ and $50 \%$ 2-WF were used in this experiment and applied in pots. $20 \%$ of Czapek medium and tap water were utilized as controls. A randomized design with 6 replicates for each treatment group was used for the pot experiment and all materials were maintained after inoculation at $25^{\circ} \mathrm{C}$ in a greenhouse with a $14 \mathrm{~h}$ light and $10 \mathrm{~h}$ dark photoperiod. Thirty-five days after transplantation, tomato roots were collected and gently washed with tap water to remove residual materials. Plant height, root fresh weight, and the total number of galls and eggs per plant root system were determined. The eggs were extracted separately from plants with a $1 \% \mathrm{NaOCl}$ method as previously described [25] and were subsequently collected in beakers with water. Afterwards, $50 \mu \mathrm{L}$ of a well-mixed egg suspension solution were transferred to a counting dish to enable egg count determination. Eggs were counted three times and the total number of eggs in the entire suspension was calculated. This experiment was repeated twice.

\subsection{Effect of Boiling and Storage Time on Nematicidal Activity Stability of Fermentation Filtrate}

Two-hundred $\mathrm{mL}$ of fresh 2-WF was dispensed into two $100 \mathrm{~mL}$ beakers respectively. One of the beakers was boiled in a microwave oven at $100^{\circ} \mathrm{C}$, whereas the second beaker was maintained at room temperature. The fermentation filtrate from two beakers were diluted to $10 \%$ and sterilized water was used as a control. Nematicidal activity was then conducted as described above and the experiment was triplicated.

For the analysis of storage time, the experiment was set up for 1-, 2-, and 3-week old 2-WF at $4{ }^{\circ} \mathrm{C}$ and $25{ }^{\circ} \mathrm{C}$ in dark, respectively; with 4 replicates for each treatment. After storage, the 2-WF solution was filtered through a sterile $0.45 \mu \mathrm{m}$ polyethersulfone filter (Whatman, Clifton, NJ, USA) and subsequently diluted to a $10 \%$ solution in sterilized water. Sterilized water alone was used as a negative control. The nematicidal activity was measured as described above and this experiment was repeated 3 times.

\subsection{Evaluation of the Strain Fermentation Filtrate on The Germination of Crop Seeds}

In this study, the effect of 2-WF of A. japonicus ZW1 was evaluated on seed germination of various crops, e.g., from corn (Qingnong 13), wheat (Mianmai 41), cowpeas (Shanlv), cabbage (Green column), cucumbers (Liaoning 8), rice (Teyou 09103), tomatoes (Hongyingguo 808), and soybeans (Ludou 4). First, healthy seeds were surface sterilized with $2 \% \mathrm{NaOCl}$ for $3 \mathrm{~min}$ and subsequently rinsed 5 times with sterilized water [33]. Seeds were treated with $10 \%$ and $20 \% 2-\mathrm{WF}$ in triplicates across 3 independent experiments, with sterilized water used as a negative control. The sterilized crop seeds were then exposed to the fermentation filtrate in a moist chamber and incubated for several days in the dark at room temperature $\left(25^{\circ} \mathrm{C}\right)$. Sprouted seeds were counted every day until the seed germination rate no longer changed. The seed germination rate was calculated as: (number of germinated seed/total tested seeds) $\times 100 \%$.

\subsection{Isolation and Structural Determination of Aspergillus Japonicus ZW-1 Nematicidal Metabolites}

Eight litre of A. japonicus ZW-1 2-week fermentation broth was filtered through 8 layers of muslin gauze, then concentrated to $500 \mathrm{~mL}$ using rotary evaporation (Hei-VAP Core ML G3, Instruments $\mathrm{GmbH} \&$ Co. Heidolph, KG, Schwabach, Germany) at $55^{\circ} \mathrm{C}$. The crude extract $(15.6 \mathrm{~g})$ from A. japonicus ZW-1 fermentation broth was extracted with 1-butanol and evaporated at $40^{\circ} \mathrm{C}$ until dry, dissolved in methanol $(\mathrm{MeOH})$ and chromatographed on methylated sephadex LH20 (Beijing Solarbio Science \& Technology Co., Ltd., Beijing, China) using $\mathrm{MeOH}$ as eluent to give two fractions, the two fractions were dissolved in distilled water to make $2.0 \mathrm{mg} \mathrm{mL}^{-1}$ aqueous solution for activity assay. One fraction showed activity against J2. This active fraction was dissolved in the chloroform, at which point white 
crystals formed. The solution was filtered through cotton which was then washed 20 times using chloroform and dried at room temperature to get the purified active compound.

The chemical structures of the active compound were determined using nuclear magnetic resonance (NMR) analysis and high-resolution electrospray ionization mass spectrometry (HR-ESI-MS) analysis. ${ }^{1} \mathrm{H}$ nuclear magnetic resonance (NMR) and ${ }^{13} \mathrm{C}$ NMR spectra were acquired in $\mathrm{MeOH}$ with a Bruker AVANCE III HD600 spectrometer (Bruker Corporation, Faellanden, Switzerland) at $600 \mathrm{MHz}$ for ${ }^{1} \mathrm{H}$ NMR spectra and $125 \mathrm{MHz}$ for ${ }^{13} \mathrm{C}$ NMR spectra using tetramethylsilane as the internal standard. HR-ESI-MS analysis was performed using a Waters E2695 model ion trap mass spectrometer (Waters, Milford, MA, USA) [34]. The nematicidal activity of active compounds at different concentrations (1.25, $1.00,0.75,0.50,0.25 \mathrm{mg} \mathrm{mL}^{-1}$ ) was measured as described above and this experimental approach was repeated 3 times. Sterilized water was used as a control.

\subsection{Statistical Analysis}

Data were analyzed using SPSS 19.0. software (SPSS Inc. Chicago, IL, USA) and statistical significance was calculated using a one-way analysis of variance (ANOVA). The means of different parameters for each treatment group were compared among each other using a Fisher's protected least significant difference (LSD) test at $p<0.05$. All figures for statistical analyses were made using Sigma Plot 10.0 (SPSS Inc., Chicago, IL, USA).

\section{Results}

\subsection{Effect of Fermentation Filtrates on Hatching of Meloidogyne Incognita Eggs}

The fermentation filtrate of $A$. japonicus ZW1 at various concentrations and different time points showed significant nematicidal activity against cumulative hatching rate of eggs. The cumulative hatching rate of eggs increased over time in the 1-WF, 2-WF, and 3-WF treatments (Figure 1). In relative comparison to 1-WF, M. incognita eggs exhibited higher sensitivity to 2-WF and 3-WF. Fifteen days after incubation, the cumulative hatching rates in $20 \%$ and $50 \% 1-\mathrm{WF}$ were $71.1 \%$ and $30.1 \%$, respectively, and were significantly lower in comparison to $2.5 \%, 5 \%$, and $10 \% 1-\mathrm{WF}$ and controls $(p<0.05)$. For the 2-WF treated samples, cumulative hatching rates in 5\%, 10\%, 20\%, and 50\% 2-WF were $42.5 \%, 36.0 \%$, $24.3 \%$, and $6.4 \%$, respectively, $15 \mathrm{~d}$ after incubation. These values were significantly lower than that of the 2.5\% 2-WF and control treatments $(p<0.05)$. Cumulative hatching rates in 5\%, 10\%, 20\%, and 50\% 3 -WF treatments were $53.0 \%, 42.2 \%, 34.6 \%$, and $21.2 \%$, respectively, $15 \mathrm{~d}$ after incubation. These results were significantly lower than that of the $2.5 \% 2-\mathrm{WF}$ and control treatments $(p<0.05)$.

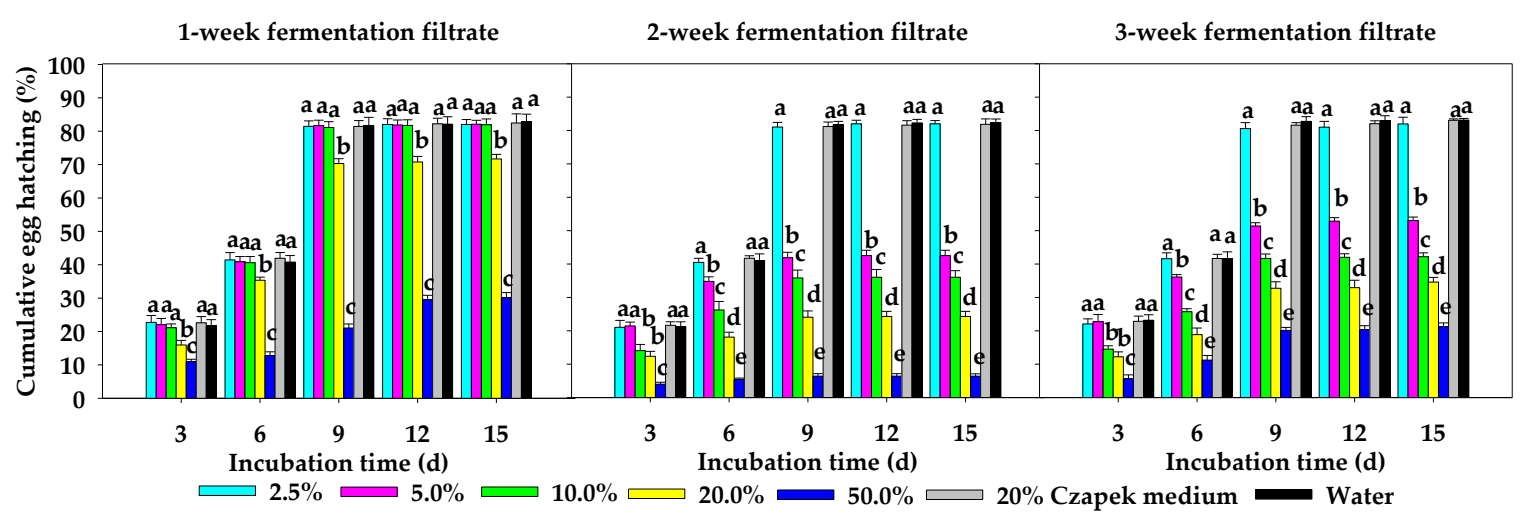

Figure 1. Cumulative Meloidogyne incognita eggs hatching rates in Aspergillus japonicus ZW1 fermentation filtrate. The bars represent the standard error. The same letter is not significantly different $(p<0.05)$ according to a Fisher's protected least significant difference (LSD) test. 


\subsection{Nematicidal Activity of Fermentation Filtrates on Meloidogyne Incognita J2s}

The time of culturing influenced the nematicidal activity of the fermentation filtrate on J2s (Figure 2). In comparison to the 1-WF and control treatments, the mortality of J2s was higher in 2-WF and 3-WF treatments at different time points post incubation. In the 1-WF treatment, the mortality of J2s was less than $3.3 \%$ and no significant difference was observed after treatment for a 6 to $48 \mathrm{~h}$ period. Conversely, application of 2-WF and 3-WF resulted in a significantly higher mortality of $\mathrm{J} 2 \mathrm{~s}$ at different concentrations of the fermentation filtrates as compared to the controls $(p<0.05)$. When investigating 50\% 2-WF and 3-WF, the mortality of J2s reached 100\% after a $6 \mathrm{~h}$ incubation period. After the $48 \mathrm{~h}$ incubation period, the mortality of 2.5\% 2-WF and 3-WF treatments reached $56.1 \%$ and $56.8 \%$, respectively, and were all significantly higher than the controls $(p<0.05)$. From a morphological perspective, treatment with 2-WF resulted in differences in the J2 when compared to the controls (Figure 3). Specifically, microscopic observations revealed that the bodies of J2s in the 2-WF treatment were either straight or arched without movements at $6 \mathrm{~h}$ post-incubation (Figure 3 , A2). However, bubbles (Figure 3, Bu) appeared in the body of J2s over time and protruded wrinkles (Figure 4, Wr) on the body surface and areas of intensive cytoplasmic vacuolization were observed (such as damaged areas; Figure 5, Da) at $10 \mathrm{~h}$ post-exposure to treatment with 2-WF.

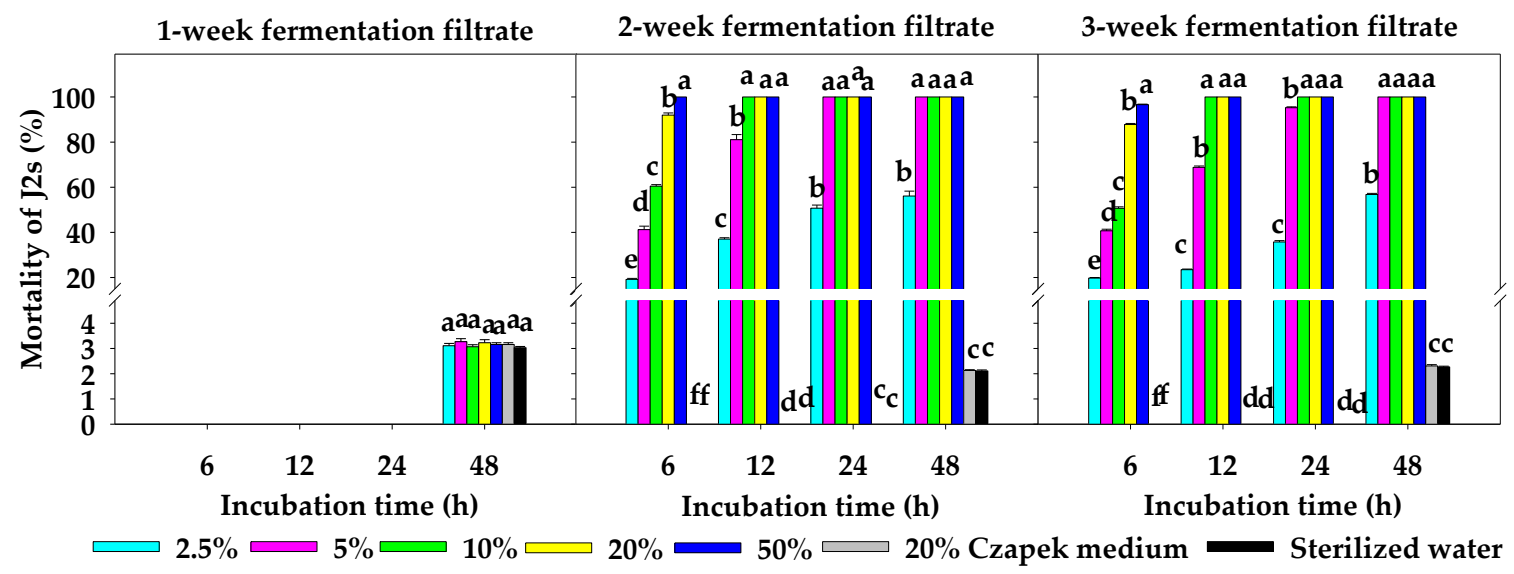

Figure 2. The mortality of Meloidogyne incognita J2s in Aspergillus japonicus ZW1 fermentation filtrate. Means with the same letter in each group designate no significant differences $(p<0.05)$ based on analysis with a Fisher's protected LSD test.

\subsection{Greenhouse Experiment}

Treatment with fermentation broth of $A$. japonicus ZW1 resulted in a significant reduction in the number of root galls and eggs per plant as compared to controls (Table 1). The number of root galls and eggs were 8.2 and 3488.9 per plant in the $50 \%$ fermentation broth treatment, respectively; whereas 16.8 and 6020 were observed per plant in the $20 \%$ fermentation broth treatment, respectively. In both treatments, the number of root galls and eggs was significantly lower than what was observed in controls $(p<0.05)$. The $50 \%$ fermentation broth decreased root galls by $78.6 \%$ and eggs by $69.4 \%$ per plant in comparison to treatment with the Czapek medium control (38.4 root galls and 11413.3 eggs) and $79.9 \%$ root galls and $72.0 \%$ eggs per plant compared with the tap water control (40.8 root galls and 12480.0 eggs, respectively), and root galls and eggs from the $20 \%$ fermentation broth treatment decreased by $56.3 \%$ and $47.3 \%$ per plant compared with the Czapek medium control (38.4 root galls and 11413.3 eggs, respectively), and $58.8 \%$ and $51.8 \%$ compared with the tap water control (40.8 root galls and 12480.0 eggs, respectively). 

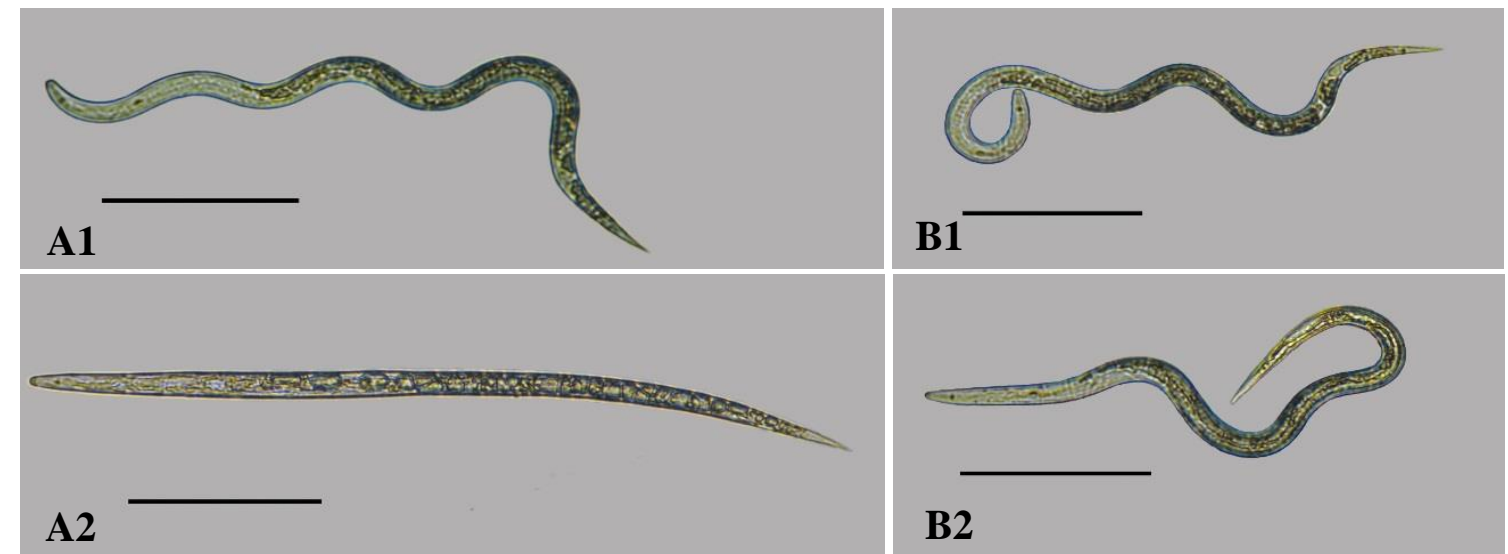

\section{B2}

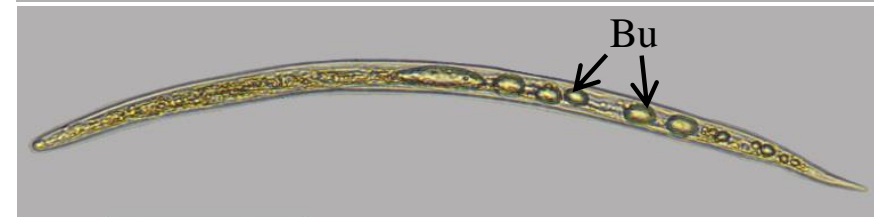

A3
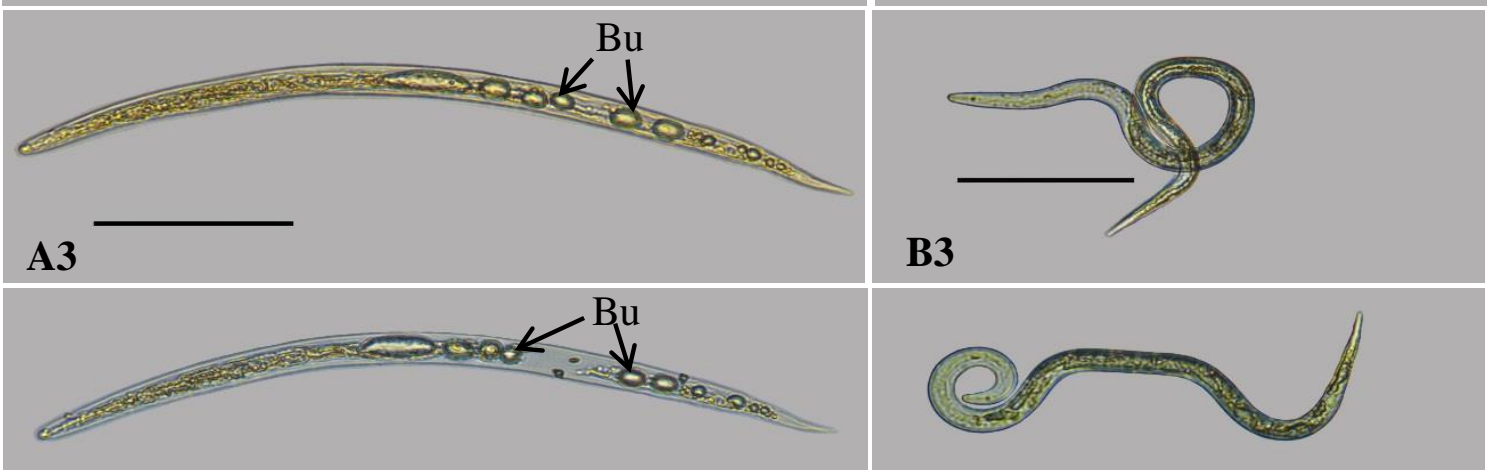

A4

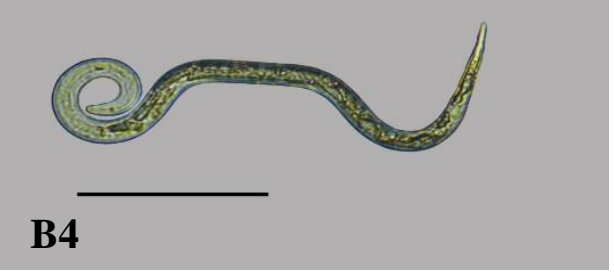

Figure 3. Morphology of second-stage juveniles of Meloidogyne incognita treated with 10\% 2-week fermentation filtrate (2-WF) of Aspergillus japonicus ZW1. A1-A4 were treated with 10\% 2-WF; B1-B4 were treated with sterilized water; $\mathbf{A 1}$ and $\mathbf{B 1}$ were treated at 0 h; $\mathbf{A} 2$ and $\mathbf{B} 2$ were treated at 6 h; A3 and B3 were treated at 12 h; and A4 and B4 were treated at $24 \mathrm{~h}$. Bu: bubbles. Scale bars of A1-A4 and B1-B4 were $100 \mu \mathrm{m}$.

Table 1. Effect of Aspergillus japonicus ZW1 fermentation broth on the formation of galls and eggs on roots and the growth of tomato plants infected with Meloidogyne incognita.

\begin{tabular}{ccccc}
\hline Treatments & Plant Height $(\mathbf{c m})$ & Fresh Root Weight $(\mathbf{g})$ & Root Galls per Plant & Egg Number per Plant \\
\hline $50 \%$ Fermentation Broth & $26.6 \pm 0.6 \mathrm{a}$ & $0.6 \pm 0.3 \mathrm{a}$ & $8.2 \pm 1.7 \mathrm{c}$ & $3488.9 \pm 155.6 \mathrm{~d}$ \\
$20 \%$ Fermentation Broth & $26.5 \pm 0.6 \mathrm{a}$ & $0.9 \pm 0.2 \mathrm{a}$ & $16.8 \pm 1.4 \mathrm{~b}$ & $6020.0 \pm 214.9 \mathrm{c}$ \\
Czapek Medium Control & $26.9 \pm 0.5 \mathrm{a}$ & $0.7 \pm 0.1 \mathrm{a}$ & $38.4 \pm 4.3 \mathrm{a}$ & $11413.3 \pm 338.9 \mathrm{~b}$ \\
Tap Water Control & $26.4 \pm 0.6 \mathrm{a}$ & $0.8 \pm 0.2 \mathrm{a}$ & $40.8 \pm 3.8 \mathrm{a}$ & $12480.0 \pm 200.4 \mathrm{a}$ \\
\hline
\end{tabular}

Values represent means \pm standard error of six replicate plants per treatment using the combination of two different experiments. Means with the same letter were not significantly different $(p<0.05)$ according to a Fisher's protected LSD test. 


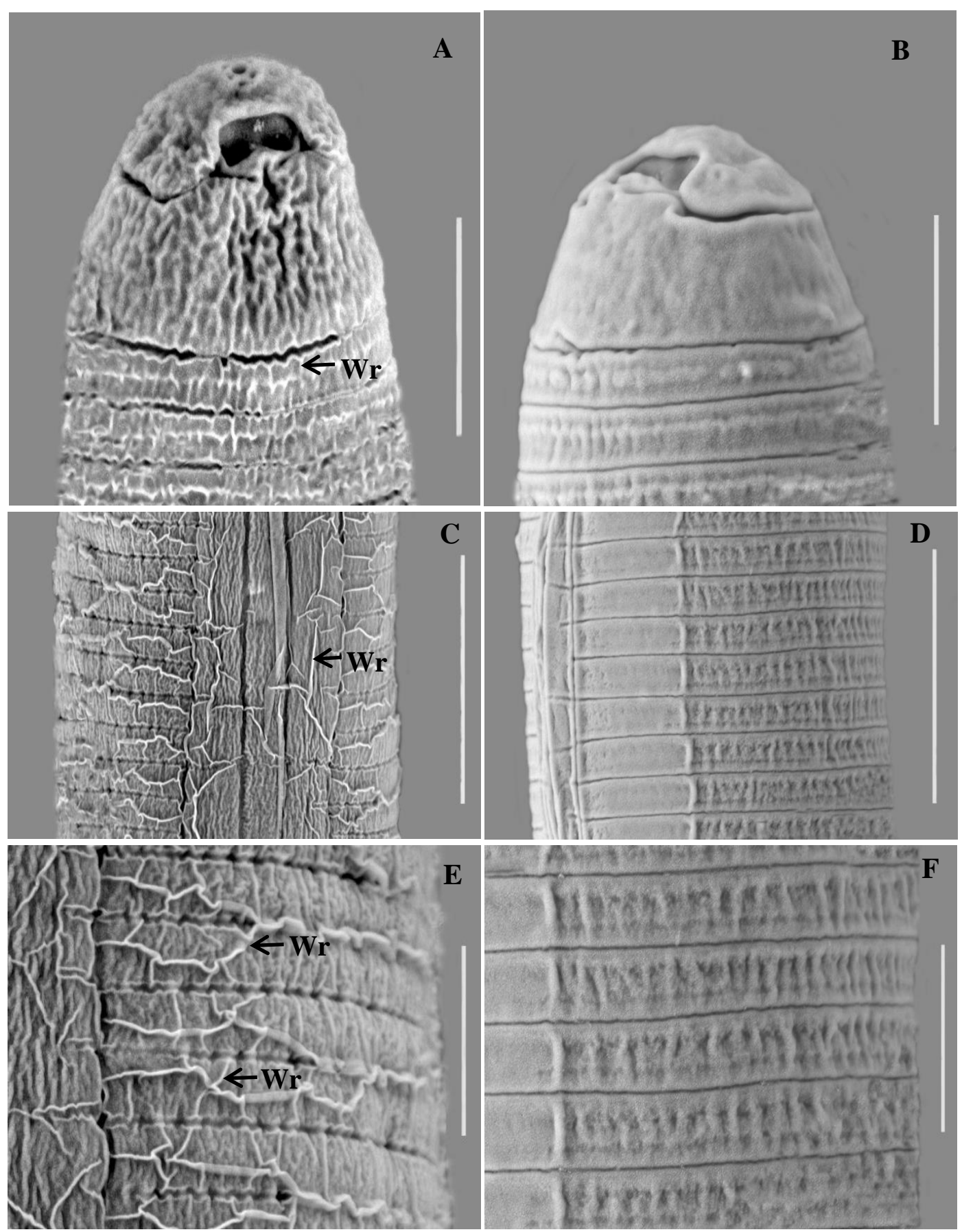

Figure 4. Visualization of the effect of $10 \%$ 2-WF of Aspergillus japonicus ZW1 on the morphology of Meloidogyne incognita J2s with scanning electron microscopy. (A,C,E) J2s treated with 10\% 2-WF. $(\mathbf{B}, \mathbf{D}, \mathbf{F}) \mathrm{J} 2 \mathrm{~s}$ treated with sterilized water. (A,B) Head region of J2. (C-F) The lateral field of J2. Scale bars of $(\mathbf{A}, \mathbf{B}, \mathbf{E}, \mathbf{F})$ and $(\mathbf{C}, \mathbf{D})$ were 2 and $5 \mu \mathrm{m}$, respectively. Wr: protruded wrinkles (black arrow). 

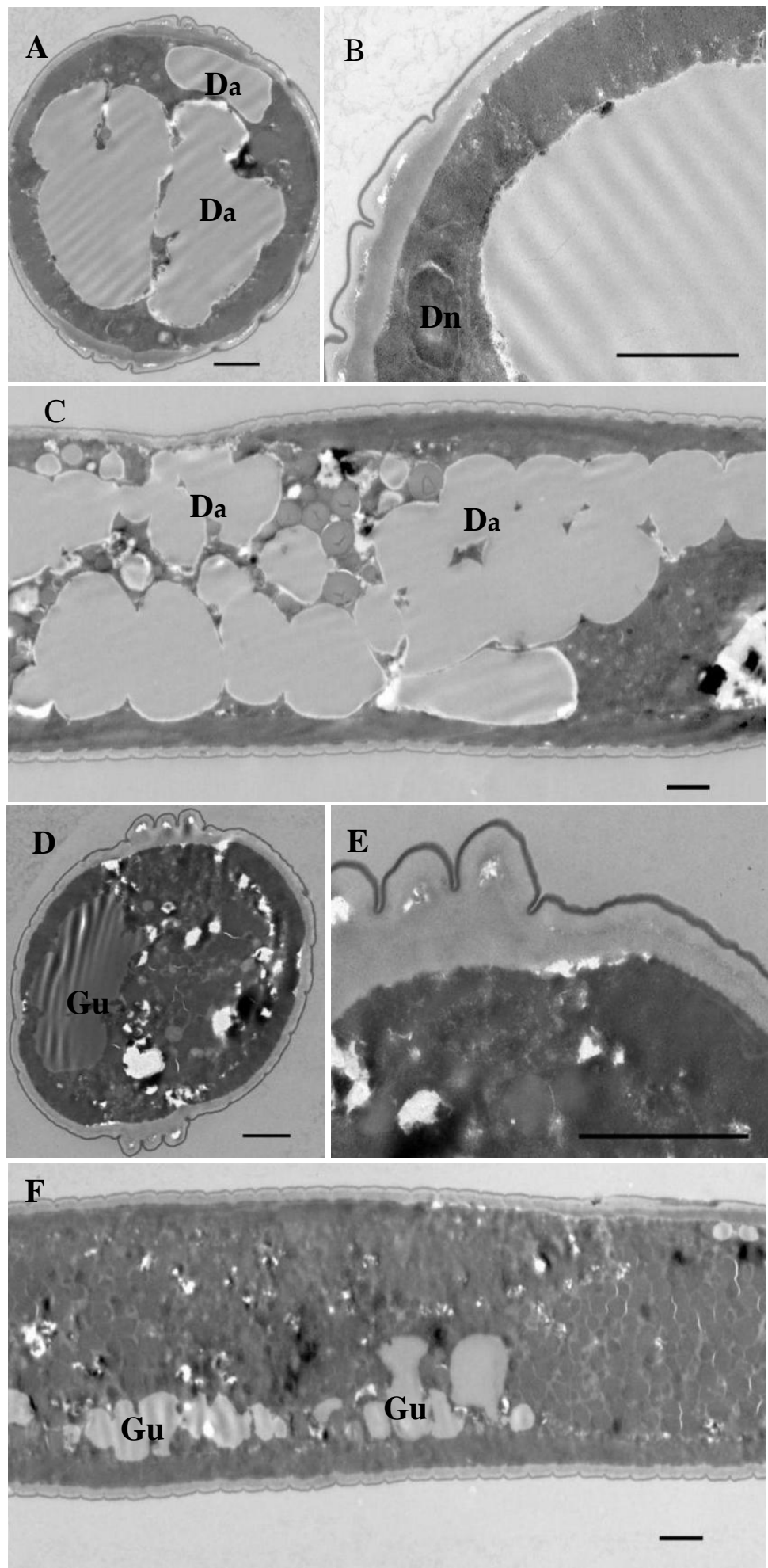

Figure 5. Cross-sections of Meloidogyne incognita J2 treated with 10\% 2-WF of Aspergillus japonicus ZW1. (A-C) J2s treated with A. japonicus ZW1 fermentation filtrate. (D-F) J2s treated with sterilized water. Scale bars of A, B, C, D, E, and F were $2 \mu \mathrm{m}$. Da: damaged and area. Gu: gut. Dn: destructed nuclei. 


\subsection{Effect of Boiling and Storage Time on the Nematicidal Activity of Fermentation Filtrate}

The mortality of J2s in fresh and boiled 10\% 2-WF did not display any significant differences (Table 2). After a $48 \mathrm{~h}$ incubation period, the mortality of $\mathrm{J} 2$ reached $100.0 \%$ in both fermentation filtrates and was significantly higher than what was observed in the sterilized water treatment $(p<0.05)$.

Table 2. Nematicidal activity of the boiled fermentation filtrate of Aspergillus japonicus ZW1 on Meloidogyne incognita J2s.

\begin{tabular}{ccccc}
\hline \multirow{2}{*}{ Treatment with 10\% 2-WF } & \multicolumn{4}{c}{ Incubation Time (h) } \\
\cline { 2 - 5 } & $\mathbf{6}$ & $\mathbf{1 2}$ & $\mathbf{2 4}$ & $\mathbf{4 8}$ \\
\hline Untreated & $44.9 \pm 5.6 \mathrm{a}$ & $91.2 \pm 3.3 \mathrm{a}$ & $91.9 \pm 3.4 \mathrm{a}$ & $99.2 \pm 0.8 \mathrm{a}$ \\
Boiled & $40.5 \pm 4.7 \mathrm{a}$ & $93.6 \pm 2.4 \mathrm{a}$ & $96.6 \pm 2.0 \mathrm{a}$ & $99.0 \pm 1.0 \mathrm{a}$ \\
Sterilized Water & $0.0 \pm 0.0 \mathrm{~b}$ & $0.0 \pm 0.0 \mathrm{~b}$ & $0.0 \pm 0.0 \mathrm{~b}$ & $0.1 \pm 0.1 \mathrm{~b}$ \\
\hline
\end{tabular}

Values represent means \pm standard deviation of three replicates. Means with the same letter are not significantly different $(p<0.05)$ according to a Fisher's protected LSD test.

No significant difference was observed in the mortality of J2s exposed to different storage conditions of 10\% 2-WF (Table 3). Specifically, they all reached $100 \%$ mortality after a $48 \mathrm{~h}$ incubation period, which was higher than the sterilized water treatment $(p<0.05)$.

Table 3. Mortality of Meloidogyne incognita J2s in Aspergillus japonicus ZW1 fermentation filtrate under different storage conditions.

\begin{tabular}{cccccc}
\hline \multirow{2}{*}{$\begin{array}{c}\text { Treatments with 10\% } \\
\text { 2-WF }\end{array}$} & Storage Time & \multicolumn{4}{c}{ Incubation Time (h) } \\
\cline { 3 - 6 } & & $\mathbf{6}$ & $\mathbf{1 2}$ & $\mathbf{2 4}$ & $\mathbf{4 8}$ \\
\hline & 1-week & $58.9 \pm 5.3 \mathrm{a}$ & $99.4 \pm 0.6 \mathrm{a}$ & $100.0 \pm 0.0 \mathrm{a}$ & $100.0 \pm 0.0 \mathrm{a}$ \\
$4{ }^{\circ} \mathrm{C}$ & 2-week & $58.3 \pm 2.2 \mathrm{a}$ & $98.8 \pm 0.7 \mathrm{a}$ & $100.0 \pm 0.0 \mathrm{a}$ & $100.0 \pm 0.0 \mathrm{a}$ \\
& 3-week & $60.8 \pm 2.2 \mathrm{a}$ & $100.0 \pm 0.0 \mathrm{a}$ & $100.0 \pm 0.0 \mathrm{a}$ & $100.0 \pm 0.0 \mathrm{a}$ \\
& 1-week & $62.1 \pm 1.8 \mathrm{a}$ & $100.0 \pm 0.0 \mathrm{a}$ & $100.0 \pm 0.0 \mathrm{a}$ & $100.0 \pm 0.0 \mathrm{a}$ \\
$25{ }^{\circ} \mathrm{C}$ & 2-week & $55.6 \pm 3.3 \mathrm{a}$ & $99.0 \pm 0.6 \mathrm{a}$ & $100.0 \pm 0.0 \mathrm{a}$ & $100.0 \pm 0.0 \mathrm{a}$ \\
& 3-week & $58.4 \pm 4.4 \mathrm{a}$ & $98.7 \pm 0.8 \mathrm{a}$ & $99.6 \pm 0.4 \mathrm{a}$ & $100.0 \pm 0.0 \mathrm{a}$ \\
Sterilized Water & - & $0.0 \pm 0.0 \mathrm{~b}$ & $0.0 \pm 0.0 \mathrm{~b}$ & $0.0 \pm 0.0 \mathrm{~b}$ & $1.4 \pm 0.8 \mathrm{~b}$ \\
\hline
\end{tabular}

Values represent the means \pm standard error of four replicates; means with the same letter are not significantly different $(p<0.05)$ according to a Fisher's protected LSD test.

\subsection{Effect of Fermentation Filtrate on Seed Germination}

The $20 \%$ and $10 \%$ 2-WF did not influenced the germination of corn, rice, tomato, cowpea, and cucumber seeds (Table 4). Two days after incubation with 10\% 2-WF, the wheat seed germination rate was $85.4 \%$ and was significantly higher than what was observed in the control $(p<0.05)$. After an extended period of time beyond the 48-h time period, this value did not increase any further. For soybean seeds treated with $10 \% 2-\mathrm{WF}$, germination was significantly lower than what was observed in sterilized water $(p<0.05)$ at day 1 ; however, there were no statistically significant differences 2-5 days post-incubation across $20 \%$ and $10 \%$ 2-WF and sterilized water treatments. For cabbage seeds, germination in 20\% 2-WF was significantly lower than what was observed in $10 \% 2$-WF and control treatments $(p<0.05)$. 
Table 4. Seed germination (\%) in different concentrations of 2-week Aspergillus japonicus ZW1 fermentation filtrate.

\begin{tabular}{cccccccc}
\hline \multirow{2}{*}{ Seeds } & Treatments & \multicolumn{7}{c}{ Incubation Time (d) } \\
\cline { 3 - 7 } & & $\mathbf{1}$ & $\mathbf{2}$ & $\mathbf{3}$ & $\mathbf{4}$ & $\mathbf{5}$ & $\mathbf{6}$ \\
\hline \multirow{5}{*}{ Wheat } & $20 \%$ & $64.6 \pm 4.5 \mathrm{a}$ & $78.1 \pm 1.8$ & $78.1 \pm 1.8$ & $78.1 \pm 1.8$ & $78.1 \pm 1.8$ & - \\
& $10 \%$ & $63.5 \pm 5.5 \mathrm{a}$ & $85.4 \pm 3.8 \mathrm{a}$ & $85.4 \pm 3.8 \mathrm{a}$ & $85.4 \pm 3.8 \mathrm{a}$ & $85.4 \pm 3.8 \mathrm{a}$ & - \\
& Sterilized Water & $60.4 \pm 4.6 \mathrm{a}$ & $72.5 \pm 1.3 \mathrm{~b}$ & $73.5 \pm 0.9 \mathrm{~b}$ & $73.5 \pm 0.9 \mathrm{~b}$ & $73.5 \pm 0.9 \mathrm{~b}$ & - \\
Corn & $20 \%$ & $10.4 \pm 1.0 \mathrm{a}$ & $83.3 \pm 1.0 \mathrm{a}$ & $88.5 \pm 2.8 \mathrm{a}$ & $88.5 \pm 2.8 \mathrm{a}$ & $88.5 \pm 2.8 \mathrm{a}$ & - \\
& $10 \%$ & $11.5 \pm 4.5 \mathrm{a}$ & $81.3 \pm 6.5 \mathrm{a}$ & $90.6 \pm 4.8 \mathrm{a}$ & $90.6 \pm 4.8 \mathrm{a}$ & $90.6 \pm 4.8 \mathrm{a}$ & - \\
& Sterilized Water & $9.4 \pm 4.8 \mathrm{a}$ & $78.1 \pm 4.8 \mathrm{a}$ & $89.6 \pm 2.1 \mathrm{a}$ & $89.6 \pm 2.1 \mathrm{a}$ & $89.6 \pm 2.1 \mathrm{a}$ & - \\
Rice & $20 \%$ & $3.0 \pm 1.8 \mathrm{a}$ & $94.0 \pm 1.8 \mathrm{a}$ & $97.0 \pm 1.8 \mathrm{a}$ & $97.0 \pm 1.8 \mathrm{a}$ & $97.0 \pm 1.8 \mathrm{a}$ & - \\
& $10 \%$ & $4.0 \pm 2.7 \mathrm{a}$ & $96.0 \pm 4.0 \mathrm{a}$ & $97.0 \pm 3.0 \mathrm{a}$ & $97.0 \pm 3.0 \mathrm{a}$ & $97.0 \pm 3.0 \mathrm{a}$ & - \\
& Sterilized Water & $1.0 \pm 1.0 \mathrm{a}$ & $90.9 \pm 3.0 \mathrm{a}$ & $93.9 \pm 1.8 \mathrm{a}$ & $93.9 \pm 1.7 \mathrm{a}$ & $93.9 \pm 1.8 \mathrm{a}$ & - \\
Tomato & $20 \%$ & 0.0 & $48.1 \pm 2.9 \mathrm{a}$ & $73.1 \pm 3.2 \mathrm{a}$ & $81.8 \pm 3.3 \mathrm{a}$ & $87.5 \pm 1.8 \mathrm{a}$ & $87.5 \pm 1.8 \mathrm{a}$ \\
& $10 \%$ & 0.0 & $51.6 \pm 2.7 \mathrm{a}$ & $69.5 \pm 3.6 \mathrm{a}$ & $79.5 \pm 4.6 \mathrm{a}$ & $89.3 \pm 3.3 \mathrm{a}$ & $91.3 \pm 3.2 \mathrm{a}$ \\
& Sterilized Water & 0.0 & $46.6 \pm 8.2 \mathrm{a}$ & $72.8 \pm 4.2 \mathrm{a}$ & $85.0 \pm 4.3 \mathrm{a}$ & $90.0 \pm 2.5 \mathrm{a}$ & $91.0 \pm 1.6 \mathrm{a}$ \\
Soybeanyyyyy & $20 \%$ & $33.3 \pm 2.8 \mathrm{ab}$ & $90.6 \pm 4.8 \mathrm{a}$ & $100.0 \pm 0.0 \mathrm{a}$ & $100.0 \pm 0.0 \mathrm{a}$ & $100.0 \pm 0.0 \mathrm{a}$ & - \\
& $10 \%$ & $26.0 \pm 5.2 \mathrm{~b}$ & $86.5 \pm 1.0 \mathrm{a}$ & $96.8 \pm 1.8 \mathrm{a}$ & $99.0 \pm 1.0 \mathrm{a}$ & $99.0 \pm 1.0 \mathrm{a}$ & - \\
& Sterilized Water & $41.8 \pm 3.8 \mathrm{a}$ & $90.6 \pm 3.6 \mathrm{a}$ & $100.0 \pm 0.0 \mathrm{a}$ & $100.0 \pm 0.0 \mathrm{a}$ & $100.0 \pm 0.0 \mathrm{a}$ & - \\
& $20 \%$ & $56.3 \pm 3.6 \mathrm{a}$ & $99.0 \pm 1.0 \mathrm{a}$ & $100.0 \pm 0.0 \mathrm{a}$ & $100.0 \pm 0.0 \mathrm{a}$ & $100.0 \pm 0.0 \mathrm{a}$ & - \\
& $10 \%$ & $64.3 \pm 7.3 \mathrm{a}$ & $100.0 \pm 0.0 \mathrm{a}$ & $100.0 \pm 0.0 \mathrm{a}$ & $100.0 \pm 0.0 \mathrm{a}$ & $100.0 \pm 0.0 \mathrm{a}$ & - \\
& Sterilized Water & $65.6 \pm 3.6 \mathrm{a}$ & $99.0 \pm 1.0 \mathrm{a}$ & $99.0 \pm 1.0 \mathrm{a}$ & $99.0 \pm 1.0 \mathrm{a}$ & $99.0 \pm 1.0 \mathrm{a}$ & - \\
Cucumberyyyyy & $20 \%$ & 100.0 & 100.0 & 100.0 & 100.0 & 100.0 & - \\
& $10 \%$ & 100.0 & 100.0 & 100.0 & 100.0 & 100.0 & - \\
& Sterilized Water & 100.0 & 100.0 & 100.0 & 100.0 & 100.0 & - \\
& $20 \%$ & $65.1 \pm 4.6 \mathrm{~b}$ & $72.1 \pm 6.9 \mathrm{~b}$ & $72.1 \pm 6.9 \mathrm{~b}$ & $72.1 \pm 6.9 \mathrm{~b}$ & $72.1 \pm 6.9 \mathrm{~b}$ & - \\
& $10 \%$ & $89.0 \pm 1.2 \mathrm{a}$ & $95.1 \pm 1.8 \mathrm{a}$ & $96.1 \pm 2.5 \mathrm{a}$ & $96.1 \pm 2.5 \mathrm{a}$ & $96.1 \pm 2.5 \mathrm{a}$ & - \\
& Sterilized Water & $77.9 \pm 4.0 \mathrm{a}$ & $95.0 \pm 3.7 \mathrm{a}$ & $95.0 \pm 3.7 \mathrm{a}$ & $95.0 \pm 3.7 \mathrm{a}$ & $95.0 \pm 3.7 \mathrm{a}$ & - \\
\hline
\end{tabular}

Values represent the means \pm standard error of four replicates; means with the same letter were not significantly different $(p<0.05)$ according to a Fisher's protected LSD test.

\subsection{Structural Confirmation of Nematicidal Substance from 2-WF}

The active compound was a pale-yellow crystal, which can dissolve easily in water. The ${ }^{1} \mathrm{H}$ NMR spectrum in $\mathrm{MeOH}$ exhibited signals due to two methyl groups at $\delta 3.68$ (each $3 \mathrm{H}, \mathrm{s}, 7,8-\mathrm{CH}_{3}$ ), 2.95, 2.85 (each $2 \mathrm{H}, \mathrm{AB}$ system, $\mathrm{d}, J=12.0 \mathrm{~Hz}, 2,4-\mathrm{CH}_{2}$ ). The ${ }^{13} \mathrm{C}$ NMR and heteronuclear multiple-quantum correlation spectra revealed two carbonyl carbons at $\delta_{\mathrm{C}} 175.00$ (s, C-6), 170.46 (s, C-1, C-5), two methoxy groups 72.84 (s, C-3), 50.78 (q, C-7, C-8), 42.63 (t, C-2, C-4). The electrospray ionization mass spectrometry (ESI-MS) data of active compound was identified the molecular formula of $\mathrm{C}_{8} \mathrm{H}_{12} \mathrm{O}_{7}$ by the $[\mathrm{M}]^{-}$ion signal at $\mathrm{m} / \mathrm{z} 219[\mathrm{M}]^{-}$. The structure of the active compound was determined to be 1,5-Dimethyl Citrate hydrochloride ester $\left(\mathrm{C}_{8} \mathrm{H}_{12} \mathrm{O}_{7} \mathrm{HCl}\right.$, Figure 6) by the analysis of its spectroscopic data and comparison with the values in the literature [35].<smiles>COC(=O)CC(O)(CC(=O)OC)C(=O)O</smiles>

Figure 6. Chemical structures of active compound from Aspergillus japonicus ZW1 fermentation filtrate.

\subsection{Effect of 1,5-Dimethyl Citrate Hydrochloride Ester on Meloidogyne Incognita J2s}

1,5-Dimethyl Citrate hydrochloride ester had a strong toxic activity against J2s at low concentrations, and J2s mortality increased with the duration of exposure in different concentration of 1,5-Dimethyl Citrate hydrochloride ester (Table 5). There were significant differences in mortality between concentrations and control after exposure $(p<0.05)$. The mortality of $\mathrm{J} 2 \mathrm{~s}$ in concentrations of $1.25,1.00,0.75,0.50$, and $0.25 \mathrm{mg} \mathrm{mL}^{-1}$ of 1,5-Dimethyl Citrate hydrochloride ester were $91.7 \%, 57.7 \%$, 
$36.9 \%, 20.8 \%$, and $3.3 \%$ respectively at $48 \mathrm{~h}$ after exposure, which were significantly higher than that of sterilized water $(p<0.05)$.

Table 5. Mortality (\%) of Meloidogyne incognita J2s in different concentrations of active compound from Aspergillus japonicus ZW-1 fermentation filtrate.

\begin{tabular}{ccccc}
\hline \multirow{2}{*}{ Concentration $\mathbf{~ m g / m L}$} & \multicolumn{4}{c}{ Incubation Time (h) } \\
\cline { 2 - 5 } & $\mathbf{6}$ & $\mathbf{1 2}$ & $\mathbf{2 4}$ & $\mathbf{4 8}$ \\
\hline 1.25 & $63.4 \pm 0.9 \mathrm{a}$ & $72.9 \pm 0.5 \mathrm{a}$ & $78.8 \pm 0.6 \mathrm{a}$ & $91.7 \pm 0.5 \mathrm{a}$ \\
1.00 & $39.9 \pm 0.7 \mathrm{~b}$ & $44.4 \pm 0.6 \mathrm{~b}$ & $47.1 \pm 0.4 \mathrm{~b}$ & $57.7 \pm 0.5 \mathrm{~b}$ \\
0.75 & $23.3 \pm 0.8 \mathrm{c}$ & $31.4 \pm 0.3 \mathrm{c}$ & $34.1 \pm 0.7 \mathrm{c}$ & $36.9 \pm 0.7 \mathrm{c}$ \\
0.50 & $2.0 \pm 0.3 \mathrm{~d}$ & $4.8 \pm 0.1 \mathrm{~d}$ & $7.9 \pm 0.2 \mathrm{~d}$ & $20.8 \pm 0.7 \mathrm{~d}$ \\
0.25 & $0.0 \pm 0.0 \mathrm{e}$ & $0.0 \pm 0.0 \mathrm{e}$ & $1.6 \pm 0.1 \mathrm{e}$ & $3.3 \pm 0.1 \mathrm{e}$ \\
Sterilized Water & $0.0 \pm 0.0 \mathrm{e}$ & $0.0 \pm 0.0 \mathrm{e}$ & $0.0 \pm 0.0 \mathrm{f}$ & $0.0 \pm 0.0 \mathrm{f}$ \\
\hline
\end{tabular}

Values represent the means \pm standard error of four replicates; means with the same letter each column were not significantly different $(p<0.05)$ according to a Fisher's protected LSD test.

Nematicidal activity of 1,5-Dimethyl Citrate hydrochloride ester was evaluated by comparing the median lethal concentrations (LC50) for different concentrations on M. incognita J2s under different exposure times. The concentrations at which $50 \%$ of the dead M. incognita J2s (LC50) were 1.0373, 0.9646, 0.9397, and $0.7614 \mathrm{mg} \mathrm{mL}^{-1} 1,5$-Dimethyl Citrate hydrochloride ester for 6, 12, 24, and $48 \mathrm{~h}$ respectively. The LC50 values were decreasing with the enhanced of exposure time (Table 6).

Table 6. Toxicity of active compound to Meloidogyne incognita J2s at different treatment durations.

\begin{tabular}{ccccc}
\hline Exposure Time $(\mathbf{h})$ & Slope $( \pm$ SE) & Correlation Coefficient & LC50 (95\%CI) & LC90 (95\%CI) \\
\hline \multirow{2}{*}{6} & $4.8790( \pm 0.2118)$ & 0.9881 & 1.0373 & 1.5283 \\
& & & $(0.9112-1.1808)$ & $(1.2756-1.8312)$ \\
12 & $5.1225( \pm 0.2843)$ & 0.9800 & 0.9646 & 1.4059 \\
24 & $5.1099( \pm 0.1618)$ & 0.9760 & $0.8229-1.1308)$ & $(1.1282-1.7520)$ \\
& & & 0.9397 & 1.9421 \\
48 & $5.4928( \pm 0.2180)$ & 0.9596 & $0.7922-1.1145)$ & $(1.4234-2.6498)$ \\
& & & $(0.6261-0.9260)$ & $(1.0971-2.1811)$ \\
\hline
\end{tabular}

LC-lethal concentration expressed in $\mathrm{mg} / \mathrm{mL}$ active compound with $95 \%$ confidence intervals (CI). SE, standard error.

\section{Discussion}

In general, the management of parasitic nematodes is a challenging process and current control strategies are mostly dependent upon the application of nematicides [36]. However, many effective nematicides have been restricted for usage and have been banned from the market in recent years due to environmental concerns [37]. Biological options are gaining attention as promising new tools due to their environmentally-friendly and non-toxic characteristics. The potential for using microbes in controlling plant-parasitic nematodes has been documented [38] and effective microbes have been obtained from soil, plants, and the surface of nematodes [39-41]. Aspergillus spp. are very common in soil and are lethal to the nematode population; $A$. niger and $A$. candidus were the potential fungal agents to be used against plant-parasitic nematodes $[35,42,43]$. The results of this study indicated that fermentation of the A. japonicus ZW1 from soil was found to not only inhibit egg hatching but was also toxic to nematodes in vitro. The 2-WF was shown to be more toxic to J2s than 1-WF and 3-WF; this effect showed the presence of more active compounds in 2-WF, worth previous characterization. The similar behavior of several fungi and bacteria were also studied against plant parasitic nematodes. Among them a culture filtrate of the rhizosphere bacterium Pseudoxanthomonas japonensis isolated from soil exhibited strong nematicidal activity against the M. incognita [30]; a metabolite of Xylaria grammica KCTC 13121BP isolated from lichen showed strong J2 killing and egg-hatching inhibitory effects [44]; 
and a culture medium of Stenotrophomonas maltophilia and Rhizobium nepotum isolated from the surface of nematodes reduced the pathogenicity of wild pine wood nematodes [39].

Natural products have many limitations, such as natural laccases, which have poor stability of enzymatic activity [45]. As a result, it was important to determine and assess if the novel environmentally-friendly nematicides could be stable for practical and durable application opportunities. Consequently, in our present study, we were interested to determine the durability of the novel biological filtrates. Importantly, the toxic activity of the A. japonicus ZW1 fermentation filtrate was not effected by boiling, storage time (1-, 2-week, and 3-week) and warm/cold conditions $\left(25^{\circ} \mathrm{C}\right.$ and $\left.4{ }^{\circ} \mathrm{C}\right)$. Usually, the surface coating of nematodes was considered to play an important role in the external protection of nematode bodies, sensing, and communication [46,47]. The microbes and plant produced several acidic metabolites or proteinases that specifically degraded the outer membrane of host cells during primary infection [42,48,49]. In our study, wrinkles on the surface of the body of J2s in 2-WF were observed with scanning electron microscopy, and internal bubbles appeared in their body over time. Additionally, other prominent changes such as intensive cytoplasmic vacuolization areas were observed using transmission electron microscopy; suggesting that the activity of compounds produced by $A$. japonicus ZW1 targeted the skin of nematodes and changed its permeability [50]. Previous research showed acidoid (acetic acid) damage the nuclei of cells and led to intensive cytoplasmic vacuolization areas in the body of J2 M. incognita [28]. Nematicidal metabolites from the endophytic fungus Chaetomium globosum YSC5 significantly reduced the reproduction of M. javanica as well [51]. In our present study, nematicidal compound 1,5-Dimethyl Citrate hydrochloride ester from A. japonicus ZW1, first isolated and identified on the basis of NMR, LC-MS techniques, was different with the nematicidal compounds produced by A. niger (oxalic acid) and A. candidus (Citric acid and 3-hydroxy-5-methoxy-3-(methoxycarbonyl)-5-oxopentanoic acid). M. incognita J2 mortality reached $100 \%$ at 1 day, and egg hatching was suppressed by $95.6 \%$ at 7 days after treated with $2 \mathrm{mmol} \mathrm{L}^{-1}$ $\left(180 \mu \mathrm{g} \mathrm{mL}^{-1}\right)$ oxalic acid [42]. 3-hydroxy-5-methoxy-3-(methoxycarbonyl)- 5-oxopentanoic acid was an isomer of 1,5-Dimethyl Citrate, which increased the mean percentage of immobile Ditylenchus destructor by $50 \%$ at a concentration of $50 \mathrm{mg} \mathrm{mL}^{-1}$ after exposure for $72 \mathrm{~h}$ [35]. In our study, M. incognita J2 treated with 1,5-Dimethyl Citrate hydrochloride ester, mortality reached $91.7 \%$ at $48 \mathrm{~h}$ after exposure to $1.25 \mathrm{mg} \mathrm{mL}^{-1}$ concentration, the LC50 was $0.7614 \mathrm{mg} \mathrm{mL}^{-1}$, which exhibited the most potent toxic activity against the $\mathrm{J} 2$ of $M$. incognita. However, the interesting thing was that in in vitro bioassay, fermentation of the strain exhibited better nematicidal effects, and the mortality of J2s reached $100 \%$ after exposed to $5 \%$ concentration (approximately $100 \mu \mathrm{g} \mathrm{mL}^{-1}$ 1,5-Dimethyl Citrate hydrochloride ester) A. japonicus ZW1 fermentation filtrate at $24 \mathrm{~h}$. Our speculation is that the nematicidal effect originated 1,5-Dimethyl Citrate hydrochloride ester combined with some other compounds produced by $A$. japonicus ZW1. Thus, we still need further study to find and proved other nematicidal activity compounds by metabonomics analysis.

No effect on the seed germination of corn, wheat, rice, cowpeas, cucumbers, soybeans, and tomatoes was observed for the $10 \%$ and $20 \%$-WF treatments. In whole pot experiments, treatment with the fermentation broth of the strain suppressed root galls and egg populations for tomatoes. As a result, these results suggested that $A$. japonicus ZW1 produced and excreted metabolites that were toxic to root-knot nematodes but did not exert negative effects on seed germination. Thus, $A$. japonicus showed desirable, effective, and safe biocontrol properties against $M$. incognita for both in vitro and greenhouse conditions. Taken together, these observations suggest that the fermentation filtrate of $A$. japonicus ZW1 is safe for use as a biological control fungus against root-knot nematodes. However, further studies are warranted and necessary to evaluate the in vivo efficacy of the strain against root-knot nematodes or other plant-parasitic nematodes.

\section{Conclusions}

A. japonicus ZW1 fermentation filtrate exhibited a potential biocidal activity on $M$. incognita in vitro and in vivo. The A. japonicus ZW1 2-week fermentation filtrate exhibited markedly inhibitory 
effects on egg hatching and nematicidal activities on J2s followed by 3-week fermentation filtrate. The A. japonicus ZW1 filtrate penetrated the body wall of $M$. incognita and caused intensive cytoplasmic vacuolization with remarkable protruded wrinkles appearing on the body surface of the J2s. Moreover, the nematicidal activity of the fermentation was stable after a boiling treatment and was not affected by storage time. A. japonicus ZW1 fermentation filtrate had no negative effect on the viability and germination of corn, wheat, rice, cowpeas, cucumbers, soybeans, and tomato seeds. The main active compound of 1,5-Dimethyl Citrate hydrochloride ester was first isolated and identified from the A. japonicus ZW1 fermentation filtrate. Finally, this work highlights the relevance of $A$. japonicus ZW1 fermentation filtrate as a potential new biological nematicide resource for the control of $M$. incognita.

Author Contributions: Conceptualization, Q.H., A.M. and H.W.; methodology, Q.H., A.M.; software, D.W.; B.L. and A.M.; validation, Q.H.; formal analysis, Q.H., A.M., D.W. and B.L.; investigation, A.M. and H.W.; resources, H.W.; data curation, Q.H., A.M. and B.L.; writing—original draft preparation, Q.H.; writing—review and editing, Q.H., A.M., D.W., and H.W.; and supervision, H.W. All authors have read and agreed to the published version of the manuscript.

Funding: This study was supported by the National Natural Science Foundation of China $(31660511,31460464)$, Guangxi Innovation Team of National Modern Agricultural Technology System (nycytxgxcxtd-10-04), Construction Project of Characteristic Specialty and Experimental Training Teaching Base (Center)-Characteristic Specialty-Plant Protection (2018-2020).

Conflicts of Interest: All authors declare they have no conflict of interest.

\section{References}

1. Fanelli, E.; Cotroneo, A.; Carisio, L.; Troccoli, A.; Grosso, S.; Boero, C.; Boero, C.; Capriglia, F.; Luca, F.D. Detection and molecular characterization of the rice root-knot nematode Meloidogyne graminicola in Italy. Eur. J. Plant Pathol. 2017, 149, 467-476. [CrossRef]

2. Kayani, M.Z.; Mukhtar, T.; Hussain, M.A. Effects of southern root knot nematode population densities and plant age on growth and yield parameters of cucumber. Crop Prot. 2017, 92, 207-212. [CrossRef]

3. Besnard, G.; Thi-Phan, N.; Ho-Bich, H.; Dereeper, A.; Nguyen, H.T.; Quénéhervé, P.; Aribi, J.; Bellafiore, S. On the close relatedness of two rice-parasitic root-knot nematode species and the recent expansion of Meloidogyne graminicola in Southeast Asia. Genes 2019, 10, 175. [CrossRef]

4. Bozbuga, R.; Dasgan, H.Y.; Akhoundnejad, Y.; Imren, M.; Günay, O.C.; Toktay, H. Effect of Mi gene and nematode resistance on tomato genotypes using molecular and screening assay. Cytol. Genet. 2020, 54, 154-164. [CrossRef]

5. Alves, G.C.S.; Ferri, P.H.; Seraphin, J.C.; Fortes, G.A.C.; Rocha, M.R.; Santos, S.C. Principal Response Curves analysis of polyphenol variation in resistant and susceptible cotton after infection by a root-knot nematode (RKN). Physiol. Mol. Plant Pathol. 2016, 96, 19-28. [CrossRef]

6. Lopes, C.M.L.; Cares, J.E.; Perina, F.J.; Nascimento, G.F.; Mendona, J.S.F.; Moita, A.W.; Castagnone-Sereno, P.; Carneiro, R.M.D.G. Diversity of Meloidogyne incognita populations from cotton and aggressiveness to Gossypium spp. accessions. Plant Pathol. 2019, 68, 816-824. [CrossRef]

7. Trudgill, D.L.; Blok, V.C. Apomictic, polyphagous root-knot nematodes: Exceptionally successful and damaging biotrophic root pathogens. Annu. Rev. Phytopathol. 2001, 39, 53-77. [CrossRef]

8. Onkendi, E.M.; Kariuki, G.M.; Marais, M.; Moleleki, L.N. The threat of root-knot nematodes (Meloidogyne spp.) in Africa: A review. Plant Pathol. 2014, 63, 727-737. [CrossRef]

9. Janati, S.; Houari, A.; Wifaya, A.; Essarioui, A.; Mimouni, A.; Hormatallah, A.; Sbaghi, M.; Dababat, A.A.; Mokrini, F. Occurrence of the root-knot nematode species in vegetable crops in Souss region of Morocco. Plant Pathol. J. 2018, 34, 308-315.

10. Seid, A.; Fininsa, C.; Mekete, T.; Decraemer, W.; Wesemael, W.M.L. Tomato (Solanum lycopersicum) and root-knot nematodes (Meloidogyne spp.)-a century-old battle. Nematology 2015, 17, 995-1009. [CrossRef]

11. Mukhtar, T.; Hussain, M.A.; Kayani, M.Z.; Aslam, M.N. Evaluation of resistance to root-knot nematode (Meloidogyne incognita) in okra cultivars. Crop Prot. 2014, 56, 25-30. [CrossRef]

12. Patel, B.K.; Patel, H.R. Effect of physical, cultural and chemical methods of management on population dynamics of phytonematodes in bidi tobacco nursery. Tob. Res. 1999, 25, 51-60. 
13. Sikora, R.A. Management of the antagonistic potential in agricultural ecosystems for the biological control of plant parasitic nematodes. Annu. Rev. Phytopathol. 1992, 30, 245-270. [CrossRef]

14. Brennan, R.J.B.; Glaze-Corcoran, S.; Wick, R.; Hashemi, M. Biofumigation: An alternative strategy for the control of plant parasitic nematodes. J. Integr. Agric. 2020, 19, 1680-1690. [CrossRef]

15. Ntalli, N.; Monokrousos, N.; Rumbos, C.; Kontea, D.; Zioga, D.; Argyropoulou, M.D.; Menkissoglu-Spiroudi, U.; Tsiropolos, N.G. Greenhouse biofumigation with Melia azedarch controls Meloidogyne spp. and enhances soil biological activity. J. Pest Sci. 2017, 91, 29-40. [CrossRef]

16. Stirling, G.R.; Wong, E.; Bhuiyan, S. Pasteuria, a bacterial parasite of plant-parasitic nematodes: Its occurrence in Australian sugarcane soils and its role as a biological control agent in naturally-infested soil. Australas. Plant Pathol. 2017, 46, 563-569. [CrossRef]

17. Viljoen, J.J.F.; Labuschagne, N.; Fourie, H.; Sikora, R.A. Biological control of the root-knot nematode Meloidogyne incognita on tomatoes and carrots by plant growth-promoting rhizobacteria. Trop. Plant Pathol. 2019, 44, 284-291. [CrossRef]

18. Hussain, M.; Zouhar, M.; Rysanek, P. Suppression of Meloidogyne incognita by the entomopathogenic fungus Lecanicillium muscarium. Plant Dis. 2018, 102, 977-982. [CrossRef]

19. Hussain, M.; Maòasová, M.; Zouhar, M.; Rysanek, P. Comparative virulence assessment of different nematophagous fungi and chemicals against northern root-knot nematodes, Meloidogyne hapla, on carrots. Pak. J. Zool. 2020, 52, 199-206. [CrossRef]

20. Nimnoi, P.; Pongsilp, N.; Ruanpanun, P. Monitoring the efficiency of Streptomyces galilaeus strain KPS-C004 against root knot disease and the promotion of plant growth in the plant-parasitic nematode infested soils. Biol. Control 2017, 114, 158-166. [CrossRef]

21. Dong, L.Q.; Zhang, K.Q. Microbial control of plant-parasitic nematodes: A five-party interaction. Plant Soil 2006, 288, 31-45. [CrossRef]

22. Li, J.; Zou, C.G.; Xu, J.P.; Ji, X.L.; Niu, X.M.; Yang, J.K.; Huang, X.W.; Zhang, K.Q. Molecular mechanisms of nematode-nematophagous microbe interactions: Basis for biological control of plant-parasitic nematodes. Annu. Rev. Phytopathol. 2015, 53, 67-95. [CrossRef]

23. Bui, H.X.; Hadi, B.A.R.; Oliva, R.; Schroeder, N.E. Beneficial bacterial volatile compounds for the control of root-knot nematode and bacterial leaf blight on rice. Crop Prot. 2020, 135, 104792. [CrossRef]

24. Nimnoi, P.; Ruanpanun, P. Suppression of root-knot nematode and plant growth promotion of chili (Capsicum flutescens L.) using co-inoculation of Streptomyces spp. Biol. Control 2020, 145, 104244. [CrossRef]

25. Hussey, R.S.; Barker, K.R. A comparison of methods of collecting inocula of Meloidogyne ssp. including a new technique. Plant Dis. Rep. 1973, 57, 1025-1028.

26. Wu, H.Y.; Silva, J.O.; Becker, J.S.; Becker, J.O. Fluazaindolizine mitigates plant-parasitic nematode activity at sublethal dosages. J. Pest Sci. 2020. [CrossRef]

27. Hahn, M.H.; Mio, L.L.M.D.; Kuhn, O.J.; Duarte, H.D.S.S. Nematophagous mushrooms can be an alternative to control Meloidogyne javanica. Biol. Control 2019, 138, 104024. [CrossRef]

28. Choi, I.H.; Kim, J.; Shin, S.C.; Park, I.K. Nematicidal activity of monoterpenoids against the pine wood nematode (Bursaphelencus xylophilus). Russ. J. Nematol. 2007, 15, 35-40.

29. Hajji-Hedfi, L.; Larayedh, A.; Hammas, N.C.; Regaieg, H.; Horrigue-Raouani, N. Biological activities and chemical composition of Pistacia lentiscus in controlling Fusarium wilt and root-knot nematode disease complex on tomato. Eur. J. Plant Pathol. 2019, 155, 281-291. [CrossRef]

30. Holland, R.J.; Williams, K.L.; Khan, A. Infection of Meloidogyne javanica by Paecilomyces lilacinus. Nematology 1999, 1, 131-139. [CrossRef]

31. Janssen, T.; Karssen, G.; Topalović, O.; Coyne, D.; Bert, W. Integrative taxonomy of root-knot nematodes reveals multiple independent origins of mitotic parthenogenesis. PLoS ONE 2017, 12. [CrossRef] [PubMed]

32. Ntalli, N.; Ratajczak, M.; Oplos, C.; Menkissoglu-Spiroudi, U.; Adamski, Z. Acetic acid, 2-undecanone, and (e)-2-decenal ultrastructural malformations on Meloidogyne incognita. J. Nematol. 2016, 48, 248-260. [CrossRef] [PubMed]

33. Zhao, J.; Liu, W.; Liu, D.; Lu, C.; Zhang, D.; Wu, H.; Dong, D.; Meng, L. Identification and evaluation of Aspergillus tubingensis as a potential biocontrol agent against grey mould on tomato. J. Gen. Plant Pathol. 2018, 84, 148-159. [CrossRef] 
34. Hu, Y.; Li, J.; Li, J.; Zhang, F.; Wang, J.; Mo, M.; Liu, Y. Biocontrol efficacy of Pseudoxanthomonas japonensis against Meloidogyne incognita and its nematostatic metabolites. FEMS Microbiol. Lett. 2019, 366, fny287. [CrossRef]

35. Shemshura, O.N.; Bekmakhanova, N.E.; Mazunina, M.N.; Meyer, S.L.F.; Rice, C.P.; Masler, E.P. Isolation and identification of nematode-antagonistic compounds from the fungus Aspergillus candidus. FEMS Microbiol. Lett. 2016, 363, fnw26. [CrossRef]

36. Desaeger, J.A.; Watson, T.T. Evaluation of new chemical and biological nematicides for managing Meloidogyne javanica in tomato production and associated double-crops in Florida. Pest Manag. Sci. 2019, 75, 3363-3370. [CrossRef]

37. Sissell, K. EPA bans carbofuran residues; sued over endosulfan. Chem. Week 2008, 170, 29.

38. Liang, L.M.; Zou, C.G.; Xu, J.Q.; Zhang, K.Q. Signal pathways involved in microbe-nematode interactions provide new insights into the biocontrol of plant-parasitic nematodes. Philos. Trans. R. Soc. B 2019, 374, 20180317. [CrossRef]

39. Liu, K.C.; Zeng, F.L.; Ben, A.L.; Han, Z.M. Pathogenicity and repulsion for toxin-producing bacteria of dominant bacteria on the surface of American pine wood nematodes. J. Phytopathol. 2017, 165, 580-588. [CrossRef]

40. Liu, M.J.; Hwang, B.S.; Zhi, J.C.; Li, W.J.; Park, D.J.; Seo, S.T.; Seo, S.T.; Kim, C.J. Screening, isolation and evaluation of a nematicidal compound from actinomycetes against the pine wood nematode, Bursaphelenchus xylophilus. Pest Manag. Sci. 2019, 75, 1585-1593. [CrossRef]

41. Ponpandian, L.N.; Rim, S.O.; Shanmugam, G.; Jeon, J.; Park, Y.H.; Lee, S.K.; Bae, H. Phylogenetic characterization of bacterial endophytes from four Pinus species and their nematicidal activity against the pine wood nematode. Sci. Rep. 2019, 9, 12457. [CrossRef] [PubMed]

42. Jang, J.Y.; Choi, Y.H.; Shin, T.S.; Kim, T.H.; Shin, K.S.; Park, H.W.; Kim, Y.; Kim, H.; Choi, G.J.; Jang, K.S.; et al. Biological control of Meloidogyne incognita by Aspergillus niger F22 producing oxalic acid. PLoS ONE 2016, 11. [CrossRef] [PubMed]

43. Jin, N.; Liu, S.M.; Peng, H.; Huang, W.K.; Kong, L.A.; Wu, Y.H.; Chen, Y.P.; Ge, F.Y.; Jian, H.; Peng, D.L. Isolation and characterization of Aspergillus niger NBC001 underlying suppression against Heterodera glycines. Sci. Rep. 2019, 9, 591. [CrossRef] [PubMed]

44. Kim, T.Y.; Jang, J.Y.; Yu, N.H.; Chi, W.J.; Bae, C.H.; Yeo, J.H.; Park, A.R.; Hur, J.S.; Park, H.W.; Park, J.Y.; et al. Nematicidal activity of grammicin produced by Xylaria grammica KCTC 13121BP against Meloidogyne incognita. Pest Manag. Sci. 2018, 74, 384-391. [CrossRef] [PubMed]

45. Kang, C.; Ren, D.; Zhang, S.; Zhang, X.; He, X.; Deng, Z.; Huang, C.; Guo, H. Effect of polyhydroxyl compounds on the thermal stability and structure of laccase. Pol. J. Environ. Stud. 2019, 28, 3253-3259. [CrossRef]

46. Spiegel, Y.; McClure, M.A. The surface coat of plant-parasitic nematodes: Chemical composition, origin, and biological role-A review. J. Nematol. 1995, 27, 127-134.

47. Curtis, R.H.C. Plant-nematode interactions: Environmental signals detected by the nematode's chemosensory organs control changes in the surface cuticle and behaviour. Parasite 2008, 15, 310-316. [CrossRef]

48. Djian, C.; Pijarowski, L.; Ponchet, M.; Arpin, N.; Favre-Bonvin, J. Acetic acid: A selective nematicidal metabolite from culture filtrates of Paecilomyces Lilacinus (Thom) Samson and Trichoderma Longibrachiatum Rifai. Nematologica 1991, 37, 101-112.

49. Phiri, A.M.; Pomerai, D.D.; Buttle, D.J.; Behnke, J.M.B. Developing a rapid throughput screen for detection of nematicidal activity of plant cysteine proteinases: The role of Caenorhabditis elegans cystatins. Parasitology 2014, 141, 164-180. [CrossRef]

50. Jatala, P. Biological control of plant-parasitic nematodes. Annu. Rev. Phytopathol. 1986, 24, 453-489. [CrossRef]

51. Khan, B.; Yan, W.; Wei, S.; Wang, Z.Y.; Zhao, S.S.; Cao, L.L.; Rajput, N.A.; Ye, Y.H. Nematicidal metabolites from endophytic fungus Chaetomium globosum YSC5. FEMS Microbiol. Lett. 2019, 366, fnz169. [CrossRef] [PubMed]

(C) 2020 by the authors. Licensee MDPI, Basel, Switzerland. This article is an open access article distributed under the terms and conditions of the Creative Commons Attribution (CC BY) license (http://creativecommons.org/licenses/by/4.0/). 